\title{
Impact of DJ-1 and Helix 8 on the Proteome and Degradome of Neuron-Like Cells
}

\author{
Ursula Kern ${ }^{1,2, \dagger}$, Klemens Fröhlich ${ }^{1,2,3,4,+}$, Johanna Bedacht ${ }^{2}$, Nico Schmidt ${ }^{2}$, Martin L. Biniossek ${ }^{2}$, \\ Nicole Gensch ${ }^{5}$, Katja Baerenfaller ${ }^{6}\left(\mathbb{D}\right.$ and Oliver Schilling ${ }^{1, *(1)}$
}

1 Institute of Surgical Pathology, Medical Center, University of Freiburg, Breisacher Straße 115a, D-79106 Freiburg, Germany

2 Institute of Molecular Medicine and Cell Research, Faculty of Medicine, University of Freiburg, 79110 Freiburg, Germany

3 Faculty of Biology, University of Freiburg, 79104 Freiburg, Germany

4 Spemann Graduate School of Biology and Medicine, University of Freiburg, 79104 Freiburg, Germany

5 Core Facility Signalling Factory, BIOSS Centre for Biological Signalling Studies, University of Freiburg, 79104 Freiburg, Germany

6 Swiss Institute of Allergy and Asthma Research (SIAF), University of Zurich, and Swiss Institute of Bioinformatics (SIB), 7265 Davos, Switzerland

* Correspondence: oliver.schilling@mol-med.uni-freiburg.de; Tel.: +49-761-27080610

+ These authors have contributed equally to this manuscript.

Citation: Kern, U.; Fröhlich, K.; Bedacht, J.; Schmidt, N.; Biniossek, M.L.; Gensch, N.; Baerenfaller, K.; Schilling, O. Impact of DJ-1 and Helix 8 on the Proteome and Degradome of Neuron-Like Cells. Cells 2021, 10, 404. https://doi.org/10.3390/ cells10020404

Academic Editor: Gerardo

\section{Z. Lederkremer}

Received: 22 December 2020

Accepted: 10 February 2021

Published: 16 February 2021

Publisher's Note: MDPI stays neutral with regard to jurisdictional claims in published maps and institutional affiliations.

Copyright: (c) 2021 by the authors. Licensee MDPI, Basel, Switzerland. This article is an open access article distributed under the terms and conditions of the Creative Commons Attribution (CC BY) license (https:/ / creativecommons.org/licenses/by/ $4.0 /)$.

\begin{abstract}
DJ-1 is an abundant and ubiquitous component of cellular proteomes. DJ-1 supposedly exerts a wide variety of molecular functions, ranging from enzymatic activities as a deglycase, protease, and esterase to chaperone functions. However, a consensus perspective on its molecular function in the cellular context has not yet been reached. Structurally, the C-terminal helix 8 of DJ-1 has been proposed to constitute a propeptide whose proteolytic removal transforms a DJ-1 zymogen to an active hydrolase with potential proteolytic activity. To better understand the cell-contextual functionality of DJ-1 and the role of helix 8, we employed post-mitotically differentiated, neuron-like SH-SY5Y neuroblastoma cells with stable over-expression of full length DJ-1 or DJ-1 lacking helix $8(\Delta \mathrm{H} 8)$, either with a native catalytically active site (C106) or an inactive site (C106A active site mutation). Global proteome comparison of cells over-expressing DJ-1 $\Delta \mathrm{H} 8$ with native or mutated active site cysteine indicated a strong impact on mitochondrial biology. N-terminomic profiling however did not highlight direct protease substrate candidates for DJ-1 $\Delta \mathrm{H} 8$, but linked DJ-1 to elevated levels of activated lysosomal proteases, albeit presumably in an indirect manner. Finally, we show that DJ-1 $\Delta \mathrm{H} 8$ loses the deglycation activity of full length DJ-1. Our study further establishes DJ-1 as deglycation enzyme. Helix 8 is essential for the deglycation activity but dispensable for the impact on lysosomal and mitochondrial biology; further illustrating the pleiotropic nature of DJ-1.
\end{abstract}

Keywords: PARK7; parkinson disease; neurodegenerative disease; protease; glycase; TAILS; proteomics; degradation; lysosome; cathepsin b

\section{Introduction}

Loss-of-function mutations in the gene PARK7, encoding the 20-kDa protein DJ-1, are associated with autosomal recessive, early-onset Parkinson's disease (PD) [1]. The assumed neuroprotective functions of DJ-1 have been attributed mainly to its effect on mitochondrial maintenance and anti-oxidant properties [2]. However, the biochemical mechanism how DJ-1 protects cells against oxidative stress and mitochondrial damage is still unclear. In numerous studies, different DJ-1 activities have been reported, including: transcriptional regulation by protein stabilization [3-5], RNA binding and translational repression [6], cellular redox sensor (reviewed in [7]), peroxidase [8], chaperone [9-11], glutathioneindependent glyoxalase [12], esterase [13], deglycase [14] and protease activity [15-18]. DJ-1 is a 189 amino acid, dimeric, evolutionary conserved protein (reviewed in [19]). It 
shares sequence homology with the PfpI family of bacterial intracellular proteases and with heat shock protein 31 (Hsp31), an Escherichia coli chaperone with protease activity. The crystal structure shows that DJ-1 contains a putative catalytic nucleophile Cys-106 (C106), which has the potential to form a Cys-His catalytic diad with His-126 [20,21]. However, the C-terminal alpha helix $\mathrm{H} 8$ appears to block access of substrates to the putative catalytic site. Weak C106-dependent proteolytic activity of purified DJ-1 was reported using casein as a substrate [18]. In vitro casein cleavage was higher in a DJ-1 truncation mutant lacking the C-terminal 15 amino acid peptide containing alpha helix $\mathrm{H} 8$, and the authors concluded that DJ-1 converts from a zymogen to an active protease by cleavage of H8 [15]. DJ-1 also showed C106-dependent catalytic activity when incubated with a peptide library with a clear preference for valine in P1 and alanine in P1' at the cleavage site [17]. Two substrates, $\mathrm{c}$-abl oncogene 1 product and kinesin family member $1 \mathrm{~B}$, were suggested in this study. In cells, in contrast to biochemical in vitro systems, protease activity and access to substrates is tightly regulated to prevent fatal damage to proteins. The identification of natural protease substrates is crucial to understanding the role of a protease in a specific physiologic context. Here we aimed to identify natural neuronal DJ-1 proteolytic substrates in human neuron-like cells using N-terminomics [22] as well as to probe the deglycase activity of DJ-1. We did not observe protease substrates that appear to be directly cleaved by DJ-1. However, our findings implicate DJ-1 in the regulation of lysosomal proteolysis. In addition, we confirm that DJ-1 protects cells from protein glycation. Helix 8 is essential for the deglycation activity but dispensable for the impact on lysosomal biology.

\section{Materials and Methods}

\subsection{Vectors and Cell Transduction}

Human DJ-1 (Ensembl: ENSG00000116288, MIM:602533) I.M.A.G.E. cDNA clone IRATp970A044D was used for site directed mutagenesis and generation of the following four different DJ-1 constructs: full length DJ-1 with wild-type C106; full length DJ-1 with active site mutated C106A; DJ-1 lacking helix 8 (C-terminal 15 residues) with wild-type C106; DJ-1 lacking helix 8 (C-terminal 15 residues) with active site mutated C106A. DJ-1 variants were cloned into a bicistronic pMIG expression vector containing an internal ribosomal entry site (IRES) and GFP allowing stoichiometric expression of untagged DJ1 variants. A three plasmid system was used for the generation of high titer retroviral particles for SH-SY5Y transduction [23]. Successfully transduced cells were selected with $800 \mu \mathrm{g} / \mathrm{ml}$ G418 for three weeks. Subpopulations of each new cell line expressing the four different DJ-1 variants or harboring the empty vector were selected by GFP-based fluorescence-assisted cell sorting (FACS) using a BD Biosciences FACS Aria flow cytometer. To confirm successful genomic integration of the respective DJ-1 constructs, genomic DNA (gDNA) of the established cell lines was isolated using a gDNA extraction kit (Qiagen), DJ-1 gDNA was amplified by PCR with a forward primer binding the vector backbone after the 5'LTTR: TACACCCTAAGCCTCCGCCT and a reverse primer binding in the DJ-1 sequence: AGGCCCCCGGCTTGTAAGA and sequenced with the sequencing primer: CCCTTGAACCTCCTCGTTCGACC.

\subsection{Cell Culture and Differentiation}

SH-SY5Y cells were purchased from LGS standards. Cells were grown in standard Dulbecco's Modified Eagle Medium DMEM/F12, Gibco, Thermo Fischer) supplemented with $10 \%$ fetal calf serum, $1 \%$ L-glutamine and $1 \%$ penicillin/streptomycin on standard plastic cell culture dishes in a sterile incubator $\left(37^{\circ} \mathrm{C}, 5 \% \mathrm{CO} 2\right)$. For differentiation a previously published protocol for the generation of a homogenous population of fully differentiated, neurotrophic factor-dependent human neuron-like cells [24] was used with minor modifications: SH-SY5Y cells were seeded at an initial density of $10^{\wedge} 4 \mathrm{cells} / \mathrm{cm}^{2}$ on Advanced cell culture dishes (Greiner). On the following three days $10 \mu \mathrm{M}$ all-trans retinoic acid (RA) was added in standard medium every $24 \mathrm{~h}$. After three days in the 
presence of RA, the cells were washed twice with DPBS and grown in serum-free medium supplemented with $50 \mathrm{ng} / \mathrm{ml}$ Brain Derived Neurotrophic Factor (BDNF) for four days.

\subsection{Cell Proliferation Measurement}

Real-time cell proliferation was assessed using the $x$ Celligence ${ }^{\circledR}$ System (Roche, Basel Switzerland). Two thousand cells per well were seeded in E-plates and differentiated as described above. Proliferation was measured in $1 \mathrm{~h}$ intervals during the course of differentiation. A BrdU ELISA (Roche Basel Switzerland) was used to determine proliferation after 7 days of differentiation according to the manufacturer's protocol. Briefly, $1 \times 10^{4}$ cells per well were seeded in a 96 well plate and differentiated as described above. At day 6 of the differentiation protocol BrdU was added for $24 \mathrm{~h}$ before fixation of the cells and immuno-detection and quantification of BrdU incorporation after 30 min incubation with anti-BrdU-POD solution and $30 \mathrm{~min}$ incubation with substrate solution. The absorbance of the samples was measured at $370 \mathrm{~nm}$ (reference wavelength: $492 \mathrm{~nm}$ ).

\subsection{Sample Preparation for Quantitative Proteomics}

Sample preparation for liquid chromatography-tandem mass spectrometry (LC-MS/MS)based proteome comparison was essentially performed as described previously [25] including denaturation and alkylation, trypsin digestion, stable isotopic labeling and prefractionation via strong cation exchange chromatography (SCX, replicates 1 and 2) or high $\mathrm{pH}$ reversed phase chromatography (hpH-RP, replicate 3).

Differentiated SH-SY5Y DJ-1 ${ }^{\mathrm{WT}} \Delta \mathrm{H} 8$ and SH-SY5Y DJ-1 ${ }^{\mathrm{C} 106 \mathrm{~A}} \Delta \mathrm{H} 8$ cells were washed three times with phosphate buffered saline (PBS), harvested with a cell scraper, and lysed on ice in lysis buffer (50 mM Tris $\mathrm{pH} 7.5,150 \mathrm{mM} \mathrm{NaCl}, 1 \% \mathrm{NP}-40,1 \%$ sodium deoxycholate, $0.02 \%$ SDS, $1 \mathrm{mM}$ EDTA) with protease inhibitors $(10 \mu \mathrm{M}$ E64d, $1 \mathrm{mM}$ PMSF and $5 \mathrm{mM}$ EDTA) added fresh to avoid protein degradation during lysis. Lysates were heat incubated for five min at $95^{\circ} \mathrm{C}$ prior to ultra-sonication for $10 \times 30 \mathrm{~s}$. For protein precipitation, cell lysates were incubated with nine volumes of ice-cold acetone and one volume of ethanol for one hour at $-80^{\circ} \mathrm{C}$. After centrifugation at $4500 \mathrm{~g}$, protein pellets were washed three times with ice-cold ethanol and reconstituted in $100 \mathrm{mM} \mathrm{NaOH}$ using ultra-sonication, followed by $\mathrm{pH}$ adjustment to 8.0 with HEPES. For the proteome comparison, samples were labeled by reductive dimethylation of primary amines either "light" (formaldehyde $\mathrm{CD} 2 \mathrm{O}$ + sodiumcyanoborohydrid $\mathrm{NaBH} 3 \mathrm{CN}$ ) or "heavy" (formaldehyde $13 \mathrm{CD} 2 \mathrm{O}$ + sodium cyanoborodeuteride $\mathrm{NaBD} 3 \mathrm{CN}$ ). The label was switched in the second experiment. Samples were pre-fractionated on C18 Hypersep columns using 15\%, 25\% and $60 \%$ acetonitrile in $1 \%$ ammonium hydroxide as elution buffers respectively.

\subsection{Sample Preparation for $N$-Terminomics}

The Terminal Amine Isotopic Labeling of Substrates (TAILS) protocol was modified from [26,27]. Cells were lysed using $5 \mathrm{mM}$ TCEP, $0.1 \%$ RapiGest, $100 \mathrm{mM}$ HEPES $\mathrm{pH}$ 8.0 and samples were immediately heat denatured for $10 \mathrm{~min}$ at $95^{\circ} \mathrm{C}$. Subsequently, DNA was sheared using ultra-sonication for $10 \times 30 \mathrm{~s}$. Iodoacetamide $(20 \mathrm{mM})$ was added for alkylation of cysteines and incubated for $30 \mathrm{~min}$ at room temperature in the dark. $\alpha$ - and $\varepsilon$-amines were labeled for $18 \mathrm{~h}$ at room temperature by adding tandem mass tag (TMT) 11 plex reagents (Thermo), which were resuspended in acetonitrile with a protein to TMT reagents mass ratio of 1:8. Following pooling of samples, sequencing grade trypsin (Worthington) was added for digestion in a trypsin to protein mass ratio of 1:50 and the sample was incubated for $2 \mathrm{~h}$ at $50{ }^{\circ} \mathrm{C}$. The same amount of trypsin was added again and the sample was incubated for $18 \mathrm{~h}$ at $37^{\circ} \mathrm{C}$. Internal peptides were then coupled to an aldehyde-functionalized polymer in the presence of $50 \mathrm{mM} \mathrm{NaBH} 3 \mathrm{CN}$ and removed from TMT-blocked N-terminal peptides by ultrafiltration through a $10 \mathrm{kDa}$ MWCO filter (Millipore, Burlington, MA, USA). The flow-through, containing TMT-blocked $\mathrm{N}$-terminal peptides, was desalted using C18 columns (Hypersep, Thermo, Waltham, MA, USA). The sample was pre-fractionated on C18 Hypersep columns using $15 \%, 25 \%$ and 
$60 \%$ acetonitrile in $1 \%$ ammonium hydroxide as elution buffers, respectively. For exact ratio determination of Cathepsin B propeptide cleavage in four independent TAILS pilot experiments was analyzed, which were performed as described previously [28].

\section{6. $L C-M S / M S$}

LC-MS/MS of the global proteome comparison was performed with a Q Exactive PLUS System (Thermo Fisher) coupled to an Easy nLC 1000 (Thermo Fisher) as described previously [29].

LC-MS/MS of the TMT TAILS experiment was measured on an Orbitrap Eclipse mass spectrometer (Thermo Fisher) coupled to an Easy nLC 1200 (Thermo Fisher). Pre-columns with $100 \mu \mathrm{m}$ ID were self-packed with $3 \mu \mathrm{m} \mathrm{C18} \mathrm{AQ} \mathrm{(Dr.} \mathrm{Maisch)} \mathrm{to} \mathrm{a} \mathrm{length} \mathrm{of} 2 \mathrm{~cm}$. A $75 \mu \mathrm{m}$ Picofrit column (New Objective) was self-packed with $1.9 \mu \mathrm{m}$ C18 AQ (Dr. Maisch) to a length of $20 \mathrm{~cm}$. Buffer A consisted of $0.1 \%$ formic acid, buffer B consisted of $80 \%$ acetonitrile in $0.1 \%$ formic acid. The samples were separated using a 70 min linear gradient from $10 \%$ to $38 \%$ B followed by a 5 min linear gradient from $38 \%$ to $47 \%$ buffer B. The mass spectrometer was operated in data dependent acquisition mode with a TMT MS2 quantitation method. A survey scan from $400-1600 \mathrm{~m} / \mathrm{z}$ at $120 \mathrm{~K}$ resolution was followed by MS2 events up to $2 \mathrm{~s}$. Standard precursor filter options from the TMT MS2 method editor node were used. For MS2 scans, peptides were fragmented using higher energy collision dissociation (HCD) with CE 38, maximum injection time $54 \mathrm{msec}$ at $30 \mathrm{~K}$ resolution with TMT and TMTpro resolution enhancement activated.

\subsection{Proteomic Data Analysis}

For proteome comparisons, raw files were analyzed using the default settings of MaxQuant [30] Version 1.6.0.16 except for the following parameter changes: The labels DimethylLys4, DimethylNterm4 and DimethylLys8, DimethylNterm8 were set. iBAQ and no variable modifications were chosen and protein quantification was allowed for label min ratio count 1 . The data were compared to a complete human reviewed database without isoforms downloaded from UniProt in June 2017 containing 20188 entries. For proteome comparisons the parameters: enzyme Trypsin, digestion mode specific ( 0 missed cleavages) and "re-quantify" were chosen.

For the TMT TAILS analysis MaxQuant Version 1.6.12.0 was used. Reporter ion MS2 with TMT11 plex and semi-tryptic enzyme specificity $(\operatorname{ArgC})$ were chosen. TAILS data were analyzed by filtering semi-tryptic peptides, more specifically, no lysine or arginine prior to the peptide sequence were allowed and initiator methionines were also excluded. Subsequently, data were z-score normalized and linear models for microarray data (LIMMA package from R) was used to detect differentially abundant peptides. Cleavage motif analysis was performed using an online tool for protease specificity characterization [31]. The Dimethylation TAILS experiments were analyzed using MaxQuant Version 1.6.14.0. Standard Quantitation with appropriate multiplicity was chosen depending on the experimental design: DimethNterm0, 4 or 8 and DimethLys0, 4 or 8 and semi-tryptic enzyme specificity $(\operatorname{ArgC})$ was chosen.

Downstream analyses were performed using Perseus [32] and R, employing linear models and differential expression for microarray data (LIMMA) [33] for the detection of differentially abundant proteins and peptides. Gene ontology enrichment analyses were performed using topGO [34]. Visualizations were created by using tidyverse [35] RColorBrewer [36] GraphPad Prism, or PVD [37].

\subsection{Western Blot}

Whole cell lysates were prepared as described for quantitative proteome comparison. Cell lysates were centrifuged at $15000 \mathrm{~g}$ for $2 \mathrm{~min}$, and protein concentration in the supernatant was determined with a bicinchoninic acid protein assay (BCA, Pierce). Equal amounts of protein extracts ( 5 to $40 \mu \mathrm{g}$ depending on the antibody used) were resolved by SDS-PAGE and transferred onto polyvinylidene fluoride (PVDF) membranes using a 
semi-dry blotting system (Bio-Rad, Hercules, CA, USA). For immune detection of proteins, membranes were probed with the following antibodies: DJ-1 (R\&D Systems 3668, Minneapolis, MN, USA), GAP43 (Böhringer 1379011, Ingelheim, Germany), ß3-Tubulin (Sigma T8660, Kavasaki, Japan), Cathepsin B (R\&D Systems AF953), methylglyoxal (MGO, Cell Biolabs Inc. STA-011, San Diego, CA, USA). $\beta$-Tubulin (Sigma Aldrich T6199) or GAPDH (abcam 9484) were used as loading control. Methylglyoxal (MGO) immunoblots were stripped by incubating the membrane with pre-heated stripping buffer (2\% SDS, $62.5 \mathrm{mM}$ Tris- $\mathrm{HCl} \mathrm{pH} \mathrm{6.8,} \mathrm{1:125} \mathrm{v/v} \mathrm{ß-mercaptoethanol)} \mathrm{at} 50{ }^{\circ} \mathrm{C}$ for $45 \mathrm{~min}$, followed by rinsing for 1-2 $\mathrm{h}$ with water and $5 \mathrm{~min}$ with TBST before they were blocked and re-probed with GAPDH antibody. Signal intensity was analyzed with ImageJ [38].

\subsection{Protein Glycation}

Differentiated SH-SY5Y cells were incubated with $5 \mathrm{mM}$ methylglyoxal (MGO) for $2 \mathrm{~h}$ under normal cell culture conditions. Cells were washed with DPBS three times and whole cell lysates were prepared as described for Western Blot. Protein glycation was probed by immunoblotting for MGO as described above.

\section{Results}

\subsection{In Vitro System of Differentiated SH SY5Y Neuron-Like Cells}

To probe for putative, natural neuronal DJ-1 proteolytic substrates we overexpressed different DJ-1 variants (Figure S1A) in the human neuroblastoma cell line SH-SY5Y with a comparatively low background of endogenous DJ-1 (Figure 1A). The putative active protease form of DJ-1, DJ-1 ${ }^{\mathrm{WT}} \Delta \mathrm{H} 8$, lacks the $15 \mathrm{C}$-terminal amino acid residues 175-189 forming helix 8 (H8), which can block substrate access to the catalytic site. In the inactivated form, DJ$1^{\mathrm{C} 106 \mathrm{~A}} \Delta \mathrm{H} 8$, the proposed catalytic nucleophile cysteine-106 (C106) was mutated to alanine (Figure S1B). For comparison, full length DJ-1 ${ }^{\mathrm{WT}}$ and DJ-1 ${ }^{\mathrm{C} 106 \mathrm{~A}}$ and the empty vector were overexpressed as well. All variants were expressed with an IRES-GFP. Subpopulations of transduced cells with equal GFP signal intensity were selected using FACS, and five different cell lines with stable overexpression of the different DJ-1 variants or the empty vector were established. Although the same gates were used for the sorting of all cell lines, higher protein expression of the full length variants in comparison to the truncated variants was observed (Figure 1A). The different overexpression levels need to be taken into consideration when directly comparing the impact of full length DJ-1 and DJ-1 $\Delta \mathrm{H} 8$ on cellular behavior.

We consider differentiated SH-SY5Y cells to be a more adequate model than nondifferentiated cells to investigate cell-physiological roles of proteins such as DJ-1; as highlighted by a proteome study comparing undifferentiated and differentiated SH-SY5Y cells, which substantiated profound differences of their respective proteome biology [39]. To this end, we differentiated the aforementioned transduced SH-SY5Y cell lines stably overexpressing different DJ-1 variants, using a protocol adapted from [24] including three days of sequential retinoic acid (RA) and subsequently four days of Brain Derived Neurotrophic Factor (BDNF) treatment (Figure 1B). Untransduced differentiated SH-SY5Y cells displayed formation and extension of neurite-like structures (Figure 1C) and dramatically reduced proliferation as shown by real-time monitoring and BrdU incorporation (Figure 1D,E). We observed a higher expression of the mature neuronal markers Growth-associated Protein 43 (GAP43) and $\beta 3$-Tubulin following differentiation (Figure 1F). Hence, we refer to these cells as neuron-like, post-mitotically differentiated cells. Each transduced cell line could be differentiated into neuron-like cells with neurite-like structures (Figure S1C). 
A
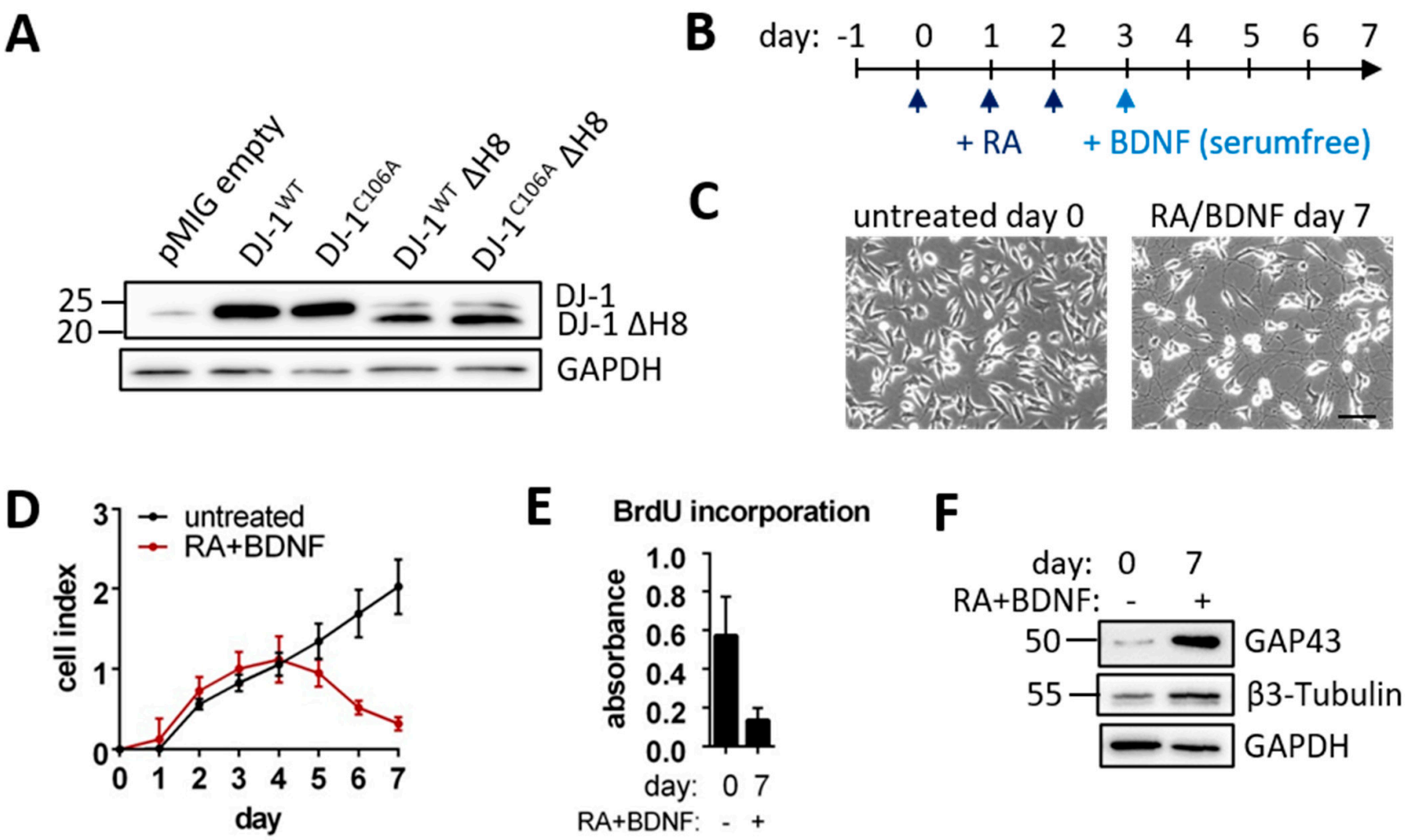

Figure 1. Established cell system: (A) DJ-1 Immunoblot of SH-SY5Y cells overexpressing different DJ-1 variants or pMIG empty vector (B) Timeline for SH-SY5Y differentiation with retinoic acid (RA) and brain derived neurotrophic factor (BDNF) (C) Micrographs of undifferentiated and differentiated SH-SY5Y cells (scale bar: $100 \mu \mathrm{m}$ ) (D) Real-time SH-SY5Y cell proliferation over 7 days of RA + BDNF treatment depicted as cell index over time of three technical replicates was assessed by absorbance at $370 \mathrm{~nm}$ (E) BrdU incorporation of untreated and RA + BDNF treated SH-SY5Y cells measured as the absorbance at $370 \mathrm{~nm}$ wavelength. (F) Immunoblots of mature neuronal markers Growth-associated Protein 43 (GAP43) and $\beta$-3-Tubulin with GAPDH as loading control.

\subsection{Degradome Analysis}

To detect putative proteolytic substrates of DJ-1 and to assess the influence of DJ-1 on the cellular degradome, we performed TAILS, an N-terminomic technique for the identification and quantification of native and proteolytically generated protein N-termini [22]. In brief, protein $\mathrm{N}$-termini and $\mathrm{N}$-termini generated by proteolytic cleavage are chemically protected and tagged with a tandem mass tag (TMT). Proteins are then subjected to tryptic digestion. The thereby generated Neo N-Termini are not chemically protected and can be depleted using an amine-reactive polymer. We compared differentiated SH-SY5Y cells overexpressing the catalytically active form DJ- ${ }^{\mathrm{WT}} \Delta \mathrm{H} 8$ to cells overexpressing the catalytically inactive form DJ-1 ${ }^{\mathrm{C} 106 \mathrm{~A}} \Delta \mathrm{H} 8$ in three replicates. We chose an 11 plex tandem mass $\operatorname{tag}$ (TMT)-based labeling approach. We identified a total of 2223 peptides, which either represent native protein $\mathrm{N}$-termini or proteolytically generated N-termini (Supplementary Table S1).

To identify differentially abundant peptides, the LIMMA package from $\mathrm{R}$ was used. As an initial step to identify enriched or underrepresented cleavage sites in connection with overexpression of different DJ-1 types, we considered N-terminal peptides with a non-adjusted $p$-value $<0.05$. As shown in Figure 2A, we detected 71 peptides enriched in $\mathrm{DJ}-1^{\mathrm{WT}} \Delta \mathrm{H} 8$ overexpressing cells as compared to $\mathrm{DJ}-1^{\mathrm{C} 106 \mathrm{~A}} \Delta \mathrm{H} 8$ overexpressing cells that fulfill this criterion. However, none of these peptides fit to the previously described sequence specificity of DJ-1: $\mathrm{V} \downarrow \mathrm{A}$, valine in P1 and alanine in P1' (Supplementary Table S1, sheet "enriched cleavage sites"). A summarized cleavage site motif is shown in Figure 2B, which shows the occurrence of amino acids of differentially abundant cleaved peptides. 
We note that P2 mostly comprises aliphatic residues, whereas $\mathrm{P} 1$ and $\mathrm{P} 1^{\prime}$ are predominantly composed of small amino acids. This motif is reminiscent of cysteine cathepsins; e.g., cathepsins B and L [40]. To investigate a potential link to lysosomal biology we probed for Cathepsin B (CTSB) activity by immunoblot. Cathepsin B is a potent lysosomal protease whose activation includes removal of its 62 residue $\mathrm{N}$-terminal domain. We verified a higher amount of activated CTSB in DJ-1 ${ }^{\mathrm{WT}} \Delta \mathrm{H} 8$ overexpressing cells compared to DJ-1 ${ }^{\mathrm{C} 106 \mathrm{~A}} \Delta \mathrm{H} 8$ or empty vector control cells (Figure $2 \mathrm{C}$ ). Analysis of TAILS peptides confirmed significantly more Cathepsin B propeptide cleavage in $\mathrm{DJ}-\mathrm{1}^{\mathrm{WT}} \Delta \mathrm{H} 8$ relative to $\mathrm{DJ}-1^{\mathrm{C} 106 \mathrm{~A}} \Delta \mathrm{H} 8$ overexpressing cells (Figure S2). A higher amount of the CTSB active form was also found in cells overexpressing full length DJ-1 ${ }^{\mathrm{WT}}$ compared to DJ-1 ${ }^{\mathrm{C} 106 \mathrm{~A}}$ or empty vector control cells (Figure 2D). In conclusion, the affected degradome of DJ$1^{\mathrm{WT}} \Delta \mathrm{H} 8$ overexpressing cells is dominated by cysteine cathepsin-type proteolysis when compared to the degradome of $\mathrm{DJ}-1^{\mathrm{C} 106 \mathrm{~A}} \Delta \mathrm{H} 8$ overexpressing cells. CTSB activation upon DJ-1 overexpression is dependent on C106 but independent of H8.

\subsection{Systemic Impact of DJ-1 $\Delta H 8$ on the Cellular Proteome}

Some of the observed altered cleavage events that could not have been generated by cysteine cathepsins, might be explained by a systemic effect of DJ- $1^{\mathrm{WT}} \Delta \mathrm{H} 8$ overexpression. To approach this question, we conducted a quantitative proteome comparison of cells overexpressing DJ-1 ${ }^{\mathrm{WT}} \Delta \mathrm{H} 8$ and cells overexpressing DJ-1 ${ }^{\mathrm{C} 106 \mathrm{~A}} \Delta \mathrm{H} 8$ (see methods). A total number of 2334, 2933 and 4421 proteins were identified in the first, second and third experiment, respectively. An overlap of 2053 proteins was consistently found in all three experiments (Figure S3A). DJ- $1^{\mathrm{WT}} \Delta \mathrm{H} 8 / \mathrm{DJ}-1^{\mathrm{C} 106 \mathrm{~A}} \Delta \mathrm{H} 8$ normalized ratios showed a normal distribution in all three experiments (Figure S3B). Alterations of protein abundances were calculated as $\log 2$ fold change (FC) values of DJ- $1^{\mathrm{WT}} \Delta \mathrm{H} 8 / \mathrm{DJ}-1^{\mathrm{C} 106 \mathrm{~A}} \Delta \mathrm{H} 8$ normalized ratios. To define proteins with altered abundance, LIMMA was used. Only proteins with an abundance change of more than $50 \%$ (FC> $|\log 2(1.5)|)$ in two of three experiments and with a non-adjusted $p$-value $\leq 0.05$ were considered to be significantly altered (Supplementary Table S2). We found 689 proteins with significantly higher abundance and 243 proteins with significantly lower abundance in DJ- $1^{\mathrm{WT}} \Delta \mathrm{H} 8$ overexpressing cells compared to DJ${ }_{1}{ }^{\mathrm{C} 106 \mathrm{~A}} \Delta \mathrm{H} 8$ overexpressing cells (Figure $3 \mathrm{~A}$ ). To interpret the pronounced effect of DJ$1^{\mathrm{WT}} \Delta \mathrm{H} 8$ on the proteome of neuron-like cells, all proteins significantly altered in abundance were clustered into gene ontology biological processes (GO BPs). The most significantly enriched GO BP terms are shown in Figure 3B,C. Proteins with a lower abundance in $\mathrm{DJ}-1^{\mathrm{WT}} \Delta \mathrm{H} 8$ are involved e.g., in membrane raft organization, beta amyloid metabolism, and integrin mediated signaling (Figure $3 \mathrm{~B}$ ). Proteins enriched in DJ-1 ${ }^{\mathrm{WT}} \Delta \mathrm{H} 8$ primarily play a role in mitochondrial processes such as mitochondrial transcription, mitochondrial translation, respiration, and mitochondrial metabolic processes including fatty acid beta oxidation and mitochondrial RNA metabolism. Many studies have shown a role of DJ-1 in maintaining proper mitochondrial function (reviewed in [41]). Here we show that Cterminally truncated DJ-1 lacking $\mathrm{H} 8$ affects mitochondrial processes in a C106-dependent manner as well. 
A

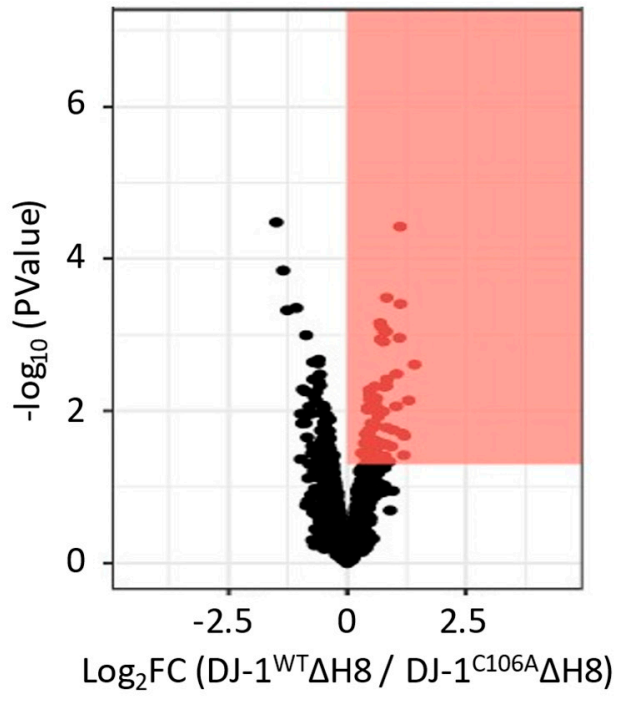

C
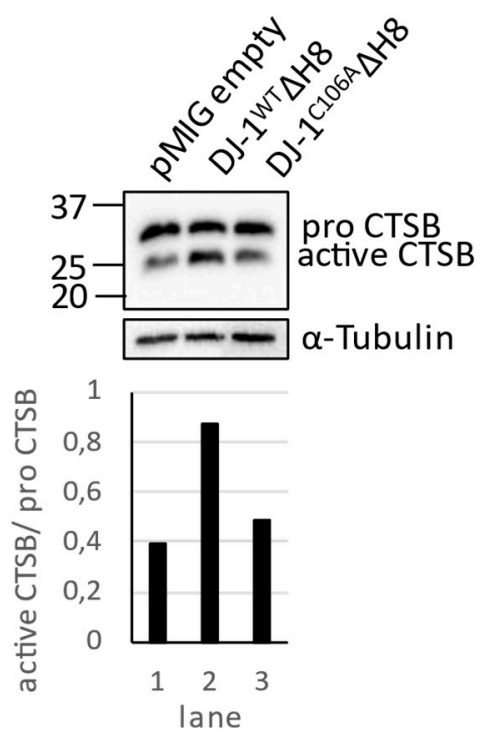

D
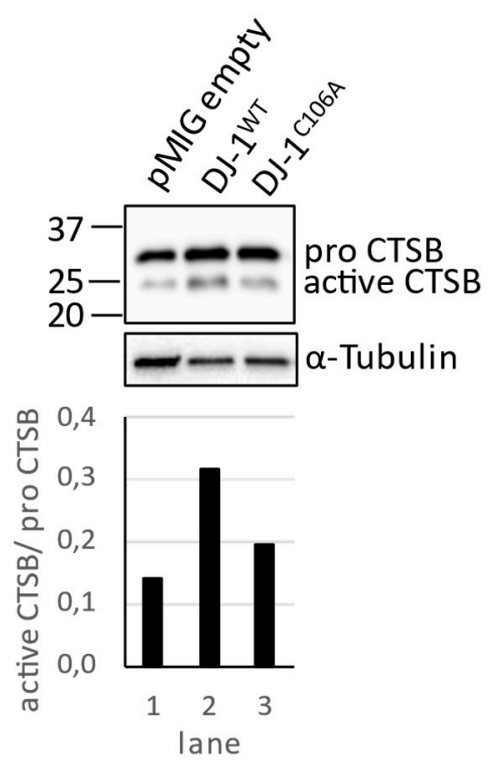

Figure 2. Degradome analysis: (A) Volcano plot representation of the TAILS experiment of DJ- $1^{\mathrm{WT}} \Delta \mathrm{H} 8$ and DJ-1 ${ }^{\mathrm{C} 106 \mathrm{~A}} \Delta \mathrm{H} 8$ overexpressing cells following LIMMA analysis, red box: proteins with higher abundance in DJ-1 ${ }^{\mathrm{WT}} \Delta \mathrm{H} 8$ cells and $\mathrm{p}_{\text {limma }}<0.05$ (B) Heatmap of the occurrence of amino acids in each position, $\mathrm{P} 6-\mathrm{P} 6{ }^{\prime}$, of peptides with higher abundance in $\mathrm{DJ}-\mathrm{1}^{\mathrm{WT}} \Delta \mathrm{H} 8$ cells following LIMMA analysis relative to the natural abundance levels of amino acids in humans (arrow and dashed line highlight the hydrolysis site, P1 to P6 were derived bioinformatically) (C,D) Cathepsin B (CTSB) Immunoblots with $\alpha$-Tubulin as loading control (upper panels) and quantification of the amount of active CTSB (lower panels).

For the investigation of a putative indirect effect of $\mathrm{DJ}-1^{\mathrm{WT}} \Delta \mathrm{H} 8$ on the degradome that we observed in the TAILS experiment, we reviewed the proteins significantly higher or lower in the quantitative proteome comparison in detail. We found several proteases with altered abundance (Figure 4). Seven mitochondrial proteases, such as Neurolysin and Mitochondrial processing peptidase subunit beta, increased in DJ-1 ${ }^{\mathrm{WT}} \Delta \mathrm{H} 8$ overexpressing cells. Also, two lysosomal proteases, namely Dipeptidyl peptidase 1 and Gamma-glutamyl hydrolase, showed higher abundance in DJ-1 ${ }^{\mathrm{WT}} \Delta \mathrm{H} 8$ overexpressing cells. In conclusion, the observed effect on the cellular degradome can partially be explained by the altered abundance of other proteases, including non-cysteine-type lysosomal proteases and mitochondrial proteases. 
A

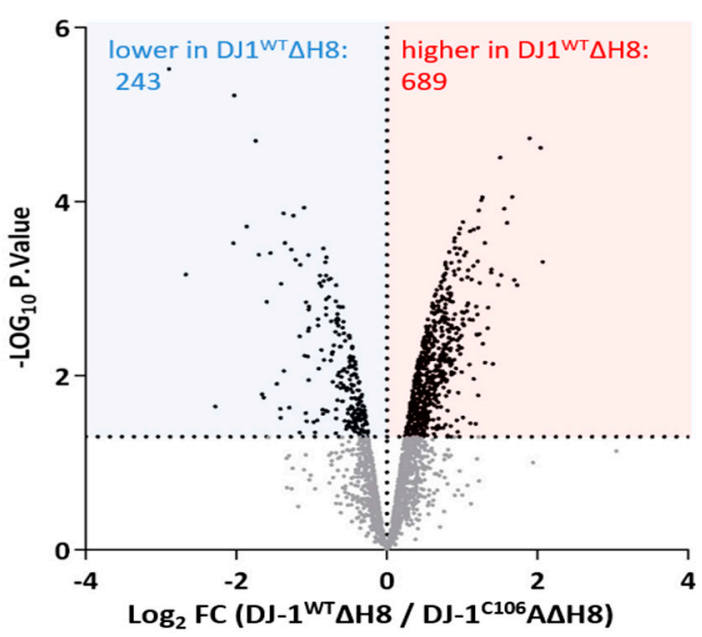

B

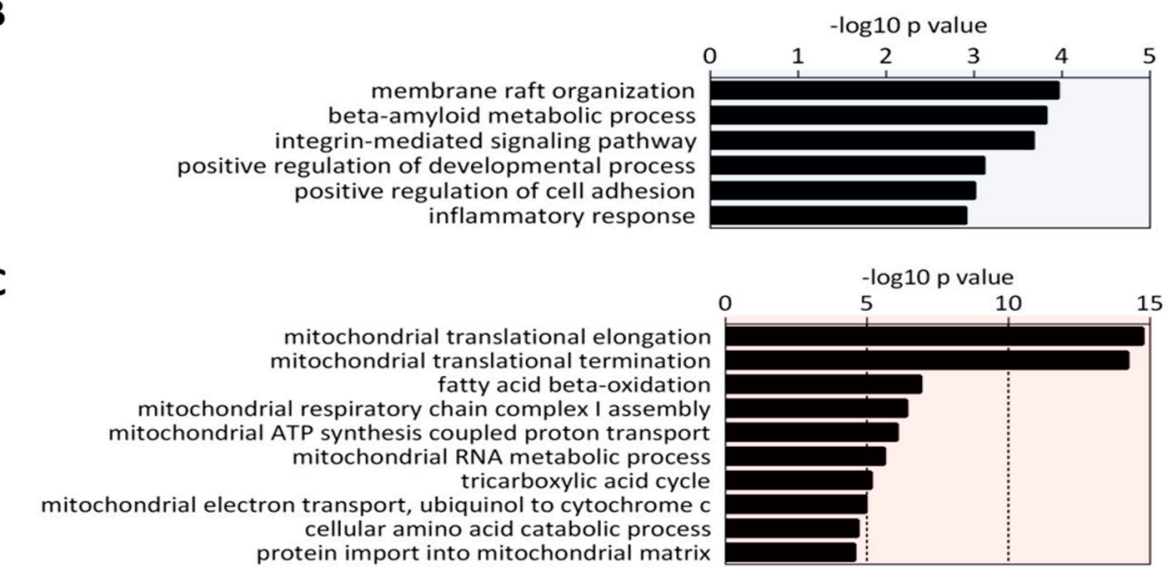

Figure 3. Systemic effect of DJ-1 $\Delta \mathrm{H} 8$ on the proteome of neuron-like cells: (A) Volcano plot representation of proteins identified in the quantitative proteome comparison of DJ- ${ }^{\mathrm{WT}} \Delta \mathrm{H} 8$ and DJ-1 ${ }^{\mathrm{C} 106 \mathrm{~A}} \Delta \mathrm{H} 8$ overexpressing differentiated SH-SY5Y cells following LIMMA analysis of three independent replicates, blue box: proteins significantly higher and red box: proteins significantly lower in DJ-1 ${ }^{\mathrm{WT}} \Delta \mathrm{H} 8(\log 2 \mathrm{FC} \leq-0.58$ or $\geq 0.58)$ in two of three experiments and $p$-value $\left.\leq 0.05\right)(\mathbf{B})$ Gene Ontology Biological Processes overrepresented by proteins significantly lower in DJ- ${ }^{\mathrm{WT}} \Delta \mathrm{H} 8$ overexpressing cells (C) Gene Ontology Biological Processes overrepresented by proteins significantly higher in $\mathrm{DJ}-1^{\mathrm{WT}} \Delta \mathrm{H} 8$ overexpressing cells.

\subsection{Protective Effect of DJ-1 on Protein Glycation}

A few years ago, DJ-1 deglycase activity was reported [14]. The authors suggested that deglycation constitutes the primary cell-physiological function of DJ-1. However, this concept has been challenged [42,43]. Using the in vitro model system of differentiated SH SY5Y cells, we probed for the potential deglycation properties of the four different DJ-1 variants. Differentiated SH-SY5Y cells were exposed to $5 \mathrm{mM}$ methylglyoxal (MGO) for $2 \mathrm{~h}$ in culture. Immunoblots of whole protein extracts with an anti-MGO antibody showed a significant decrease of protein glycation in cells overexpressing DJ-1 ${ }^{\mathrm{WT}}$ compared to empty vector control cells (Figure $5 \mathrm{~A}$ ), which was abolished in the DJ-1 ${ }^{\mathrm{C} 106 \mathrm{~A}}$ mutant. These results confirm a C106-dependent protective effect of DJ-1 on protein glycation in neuron-like cells. In contrast, protein glycation was not decreased in DJ-1 $\Delta \mathrm{H} 8$ overexpressing cells compared to empty vector control cells (Figure 5B). Our findings corroborate that DJ-1 protects proteins from glycation and we show that the C-terminal Helix 8 (H8) is essential for this protective effect. 


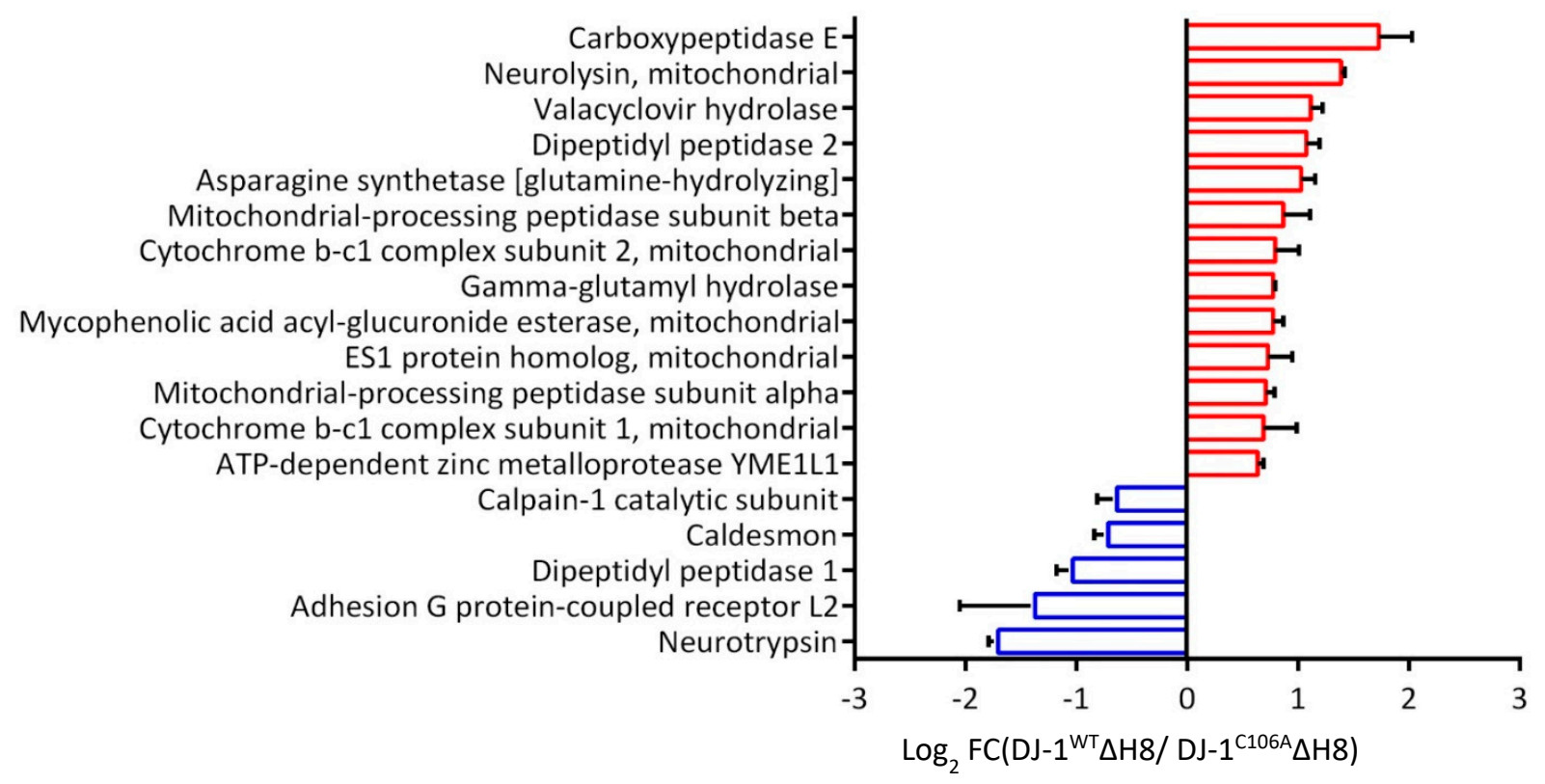

Figure 4. Effect of DJ-1 $\Delta \mathrm{H} 8$ overexpression on the abundance of other proteases: Proteases with significantly altered abundance in the quantitative proteome comparison of DJ- $1^{\mathrm{WT}} \Delta \mathrm{H} 8$ and $\mathrm{DJ}-1^{\mathrm{C} 106 \mathrm{~A}} \Delta \mathrm{H} 8$ overexpressing differentiated SH-SY5Y cells ( $\log 2 \mathrm{FC} \leq-0.58$ or $\geq 0.58)$ in two of three experiments and $p$-value $\leq 0.05)$.
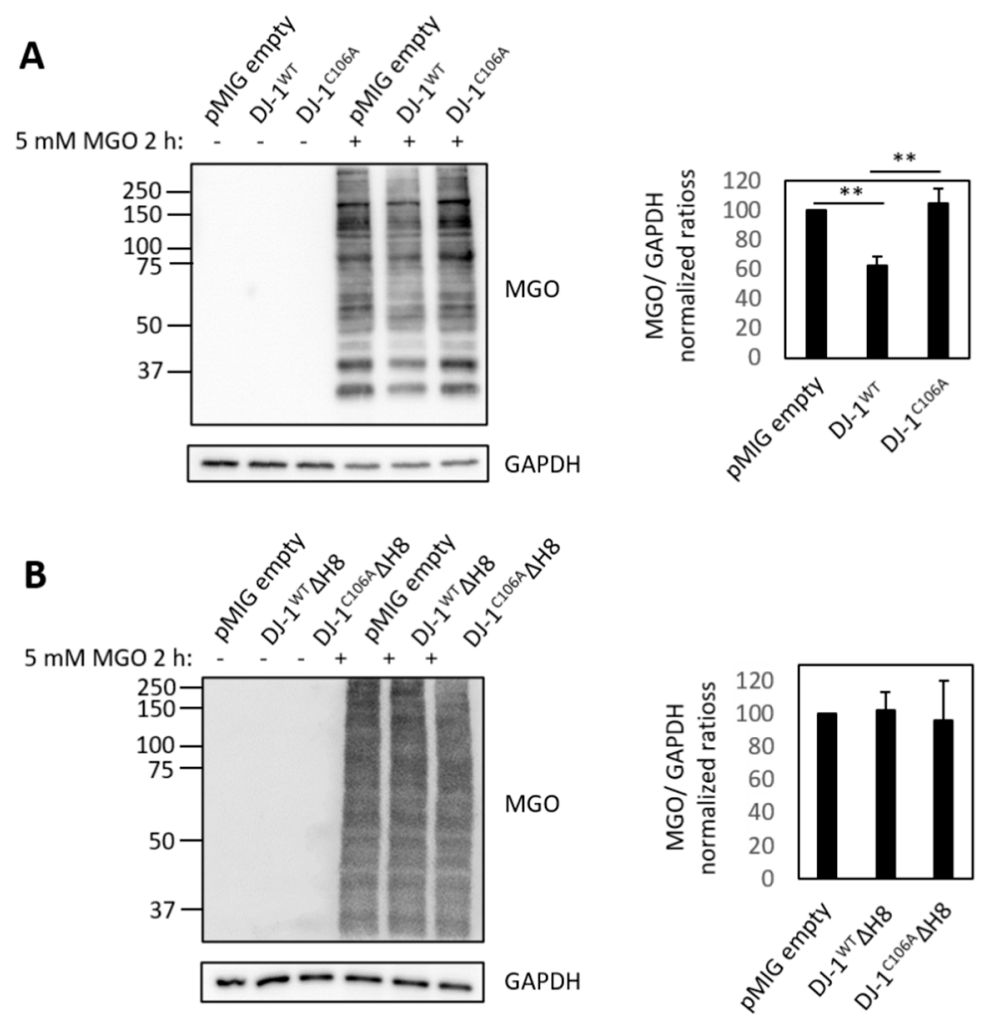

Figure 5. Effect of DJ-1 on protein glycation: Effect on protein glycation by overexpression of (A) full length DJ-1 variants DJ-1 ${ }^{\mathrm{WT}}$ and DJ-1 ${ }^{\mathrm{C} 106 \mathrm{~A}}$ and (B) C-terminally truncated DJ-1 variants; left: Immunoblots of whole cell lysates of untreated and MGO treated cells expressing different DJ-1 variants with anti-MGO antibody and GAPDH as loading control: right: quantification of signal intensity of MGO-modified proteins relative to empty vector control (pMIG empty) with ImageJ of three independent experiments for full length variants and two independent experiments for C-terminally truncated variants ${ }^{* *} p \leq 0.01$ by two tailed t-test on independent groups). 


\section{Discussion}

DJ-1 plays a role in tumor progression (reviewed in [44]) and DJ-1 loss-of-function is associated with autosomal early-onset Parkinson's disease [1]. DJ-1 protects cells from oxidative stress [7], but its precise function remains elusive. The aim of the present study is to further our understanding of the cell-physiological roles of DJ-1 and their dependence on helix 8, which supposedly acts as a propeptide. Due to the suggested role of DJ-1 in neurodegenerative diseases, we employed an in vitro model of post-mitotically differentiated, neuron-like cells.

While our N-terminomic analysis revealed differences in the degradome between DJ$1^{\mathrm{WT}} \Delta \mathrm{H} 8$ and $\mathrm{DJ}-1^{\mathrm{C} 106 \mathrm{~A}} \Delta \mathrm{H} 8$ overexpressing cells, we did not find quantitatively affected $\mathrm{N}$-termini that match the sequence specificity of proteolytically active DJ-1 (V $\downarrow \mathrm{A})$ that was determined in vitro before [17]. We note that this finding does not refute DJ-1 acting as an endoprotease in cellulo. It is possible that putative DJ-1 substrates were absent in differentiated SH-SY5Y cells. Furthermore, it is possible that DJ-1 cleavage products are prone to rapid degradation, hence escaping detection by N-terminomics.

Independent of direct DJ-1 substrates, we found increased levels of several other, mainly mitochondrial and lysosomal, proteases and observed a pronounced, yet indirect impact of DJ-1 on cysteine cathepsin-type proteolysis. This impact depends on the presence of $\mathrm{C} 106$ but is independent of H8. Of note, we do not postulate that DJ-1 directly activates Cathepsin B but consider this an indirect, yet dominant effect whose mechanistic underpinning remains beyond the findings of the present study. Our findings are in line with previous reports that link the cell-physiological function of DJ-1 to lysosomal biology: Gao and colleagues reported increased autophagy upon DJ-1 overexpression [45] and other groups showed reduced autophagy upon loss of DJ-1 [46,47]. The link between DJ-1 and autophagy awaits further mechanistic clarification.

The quantitative proteome comparison of DJ- $1^{\mathrm{WT}} \Delta \mathrm{H} 8$ and $\mathrm{DJ}-1^{\mathrm{C} 106 \mathrm{~A}} \Delta \mathrm{H} 8$ overexpressing cells showed an increase of mitochondrial proteins in DJ-1 ${ }^{\mathrm{WT}} \Delta \mathrm{H} 8$. The protective function of DJ-1 on mitochondria and the reduction of reactive oxygen species was observed before in several studies (reviewed in [41]). Proteins more abundant in DJ- ${ }^{\mathrm{WT}} \Delta \mathrm{H} 8$ overexpressing cells are involved in biological processes such as mitochondrial translation, complex I assembly and transport into mitochondria, which are important for mitochondrial biogenesis. Hence it is conceivable that DJ-1 is not only linked to the maintenance but also to the biogenesis of mitochondria.

Interestingly, we observed an effect on mitochondrial and lysosomal biology when overexpressing the truncated form DJ-1 ${ }^{\mathrm{WT}} \Delta \mathrm{H} 8$. DJ-1 exists as a homodimer in cells, which is its expected active form. Based on its crystal structure, a novel mode of dimerization mediated by C-terminal helix $\mathrm{H} 8$ was suggested [21]. It remains to be determined whether DJ-1 dimerization is dependent on H8 or whether it may also function as a monomer. We observed lower protein amounts of the overexpressed truncated versions in comparison to the DJ-1 full length versions despite an equal expression of GFP in the bicistronic system. This could mean that the half live of DJ-1 $\Delta \mathrm{H} 8$ is shorter than that of full length DJ-1.

The accumulation of glycated proteins and lipids, which represent so-called "advanced glycation end products" (AGE), is a feature of neurodegenerative diseases. Proteins and lipids become glycated by the exposure to reducing sugars such as MGO. The accumulation of AGE may contribute to the development of neurodegenerative disease [48]. A protective effect of DJ-1 against protein glycation has been shown in yeast, bacteria [49] and human keratinocytes [50]. Whether DJ-1 detoxifies free MGO by acting as a glyoxalase [12,42,51] or removes adducts formed by MGO on proteins by acting as a deglycase [14,52] is a matter of debate. Here we confirm a C106-dependent protective effect of DJ-1 on protein glycation in neuron-like cells and show that in our cellular system H8 is essential for this effect.

In summary, we used neuron-like SH-SY5Y cells to study the physiological role(s) of DJ-1 $\Delta \mathrm{H} 8$. We were unsuccessful in identifying DJ-1 proteolytic substrates, but our findings strengthen the impact of DJ-1 on lysosomal and mitochondrial biology, as well as its protective role against protein glycation. All of these activities depend on the presence 
of cysteine 106, while the C-terminal Helix 8 (H8) is dispensable for the link to lysosomal biology.

Supplementary Materials: The following are available online at https://www.mdpi.com/2073 $-4409 / 10 / 2 / 404 / s 1$, Figure S1: Cell system. Figure S2: Quantitative proteome comparison of differentiated DJ-1 ${ }^{\mathrm{WT}} \Delta \mathrm{H} 8$ and DJ-1 ${ }^{\mathrm{C} 106 \mathrm{~A}} \Delta \mathrm{H} 8$ overexpressing SH-SY5Y cells. Table S1: 2020-11-23, Table S2: 2020-11-30.

Author Contributions: Conceptualization, U.K., K.F., J.B., O.S. Methodology, U.K., K.F., M.L.B., N.G., K.B., O.S. Validation, U.K., K.F., J.B., N.S. Formal analysis, U.K., K.F., M.L.B., K.B., O.S. Investigation, U.K., K.F., J.B., N.S. Resources, N.G., K.B., O.S. Data curation, U.K., K.F., M.L.B., O.S. Writingoriginal draft preparation, U.K., K.F., N.G., K.B., O.S. Writing-review and editing, U.K., K.F., N.G., K.B., O.S. Visualization, U.K., K.F. Supervision, O.S. Project administration, O.S. Funding acquisition, K.B., O.S. All authors have read and agreed to the published version of the manuscript.

Funding: OS acknowledges funding by DFG (CRC 850, Z1; PA 2807/3-1; SCHI 871/11-1; SCHI 871/15-1; GR 4553/5-1). KB acknowledges funding by the canton of Grisons (protocol nr 628) and the Hans Groeber Foundation.

Institutional Review Board Statement: Not applicable.

Informed Consent Statement: Not applicable.

Data Availability Statement: Raw Data of mass spectrometry experiments is accessible via MassIVE: ftp:/ /MSV000086626@massive.ucsd.edu (accessed on 10 February 2021); reviewer password "ImpactofDJ1".

Conflicts of Interest: The authors declare no conflicting interests.

\section{References}

1. Bonifati, V.; Rizzu, P.; van Baren, M.J.; Schaap, O.; Breedveld, G.J.; Krieger, E.; Dekker, M.C.; Squitieri, F.; Ibanez, P.; Joosse, M.; et al. Mutations in the DJ-1 gene associated with autosomal recessive early-onset parkinsonism. Science 2003, 299, 256-259. [CrossRef] [PubMed]

2. Cookson, M.R. DJ-1, PINK1, and their effects on mitochondrial pathways. Mov. Disord. 2010, 25 (Suppl. 1), S44-S48. [CrossRef]

3. Clements, C.M.; McNally, R.S.; Conti, B.J.; Mak, T.W.; Ting, J.P. DJ-1, a cancer- and Parkinson's disease-associated protein, stabilizes the antioxidant transcriptional master regulator Nrf2. Proc. Natl. Acad. Sci. USA 2006, 103, 15091-15096. [CrossRef] [PubMed]

4. Fan, J.; Ren, H.; Jia, N.; Fei, E.; Zhou, T.; Jiang, P.; Wu, M.; Wang, G. DJ-1 decreases Bax expression through repressing p53 transcriptional activity. J. Biol. Chem. 2008, 283, 4022-4030. [CrossRef] [PubMed]

5. McNally, R.S.; Davis, B.K.; Clements, C.M.; Accavitti-Loper, M.A.; Mak, T.W.; Ting, J.P. DJ-1 enhances cell survival through the binding of Cezanne, a negative regulator of NF-kappaB. J. Biol. Chem. 2011, 286, 4098-4106. [CrossRef]

6. van der Brug, M.P.; Blackinton, J.; Chandran, J.; Hao, L.Y.; Lal, A.; Mazan-Mamczarz, K.; Martindale, J.; Xie, C.; Ahmad, R.; Thomas, K.J.; et al. RNA binding activity of the recessive parkinsonism protein DJ-1 supports involvement in multiple cellular pathways. Proc. Natl. Acad. Sci. USA 2008, 105, 10244-10249. [CrossRef] [PubMed]

7. Raninga, P.V.; Di Trapani, G.; Tonissen, K.F. The Multifaceted Roles of DJ-1 as an Antioxidant. Adv. Exp. Med. Biol. 2017, 1037, 67-87. [CrossRef]

8. Andres-Mateos, E.; Perier, C.; Zhang, L.; Blanchard-Fillion, B.; Greco, T.M.; Thomas, B.; Ko, H.S.; Sasaki, M.; Ischiropoulos, H.; Przedborski, S.; et al. DJ-1 gene deletion reveals that DJ-1 is an atypical peroxiredoxin-like peroxidase. Proc. Natl. Acad. Sci. USA 2007, 104, 14807-14812. [CrossRef]

9. Girotto, S.; Cendron, L.; Bisaglia, M.; Tessari, I.; Mammi, S.; Zanotti, G.; Bubacco, L. DJ-1 is a copper chaperone acting on SOD1 activation. J. Biol. Chem. 2014, 289, 10887-10899. [CrossRef]

10. Shendelman, S.; Jonason, A.; Martinat, C.; Leete, T.; Abeliovich, A. DJ-1 is a redox-dependent molecular chaperone that inhibits alpha-synuclein aggregate formation. PLoS Biol. 2004, 2, e362. [CrossRef]

11. Zhou, W.; Zhu, M.; Wilson, M.A.; Petsko, G.A.; Fink, A.L. The oxidation state of DJ-1 regulates its chaperone activity toward alpha-synuclein. J. Mol. Biol. 2006, 356, 1036-1048. [CrossRef]

12. Lee, J.Y.; Song, J.; Kwon, K.; Jang, S.; Kim, C.; Baek, K.; Kim, J.; Park, C. Human DJ-1 and its homologs are novel glyoxalases. Hum. Mol. Genet. 2012, 21, 3215-3225. [CrossRef] [PubMed]

13. Vazquez-Mayorga, E.; Diaz-Sanchez, A.G.; Dagda, R.K.; Dominguez-Solis, C.A.; Dagda, R.Y.; Coronado-Ramirez, C.K.; MartinezMartinez, A. Novel Redox-Dependent Esterase Activity (EC 3.1.1.2) for DJ-1: Implications for Parkinson's Disease. Int. J. Mol. Sci. 2016, 17, 1346. [CrossRef] 
14. Richarme, G.; Mihoub, M.; Dairou, J.; Bui, L.C.; Leger, T.; Lamouri, A. Parkinsonism-associated protein DJ-1/Park7 is a major protein deglycase that repairs methylglyoxal- and glyoxal-glycated cysteine, arginine, and lysine residues. J. Biol. Chem. 2015, 290, 1885-1897. [CrossRef]

15. Chen, J.; Li, L.; Chin, L.S. Parkinson disease protein DJ-1 converts from a zymogen to a protease by carboxyl-terminal cleavage. Hum. Mol. Genet. 2010, 19, 2395-2408. [CrossRef]

16. Koide-Yoshida, S.; Niki, T.; Ueda, M.; Himeno, S.; Taira, T.; Iguchi-Ariga, S.M.; Ando, Y.; Ariga, H. DJ-1 degrades transthyretin and an inactive form of DJ-1 is secreted in familial amyloidotic polyneuropathy. Int. J. Mol. Med. 2007, 19, 885-893. [CrossRef] [PubMed]

17. Mitsugi, H.; Niki, T.; Takahashi-Niki, K.; Tanimura, K.; Yoshizawa-Kumagaye, K.; Tsunemi, M.; Iguchi-Ariga, S.M.; Ariga, H. Identification of the recognition sequence and target proteins for DJ-1 protease. FEBS Lett. 2013, 587, 2493-2499. [CrossRef] [PubMed]

18. Olzmann, J.A.; Brown, K.; Wilkinson, K.D.; Rees, H.D.; Huai, Q.; Ke, H.; Levey, A.I.; Li, L.; Chin, L.S. Familial Parkinson's disease-associated L166P mutation disrupts DJ-1 protein folding and function. J. Biol. Chem. 2004, 279, 8506-8515. [CrossRef]

19. Smith, N.; Wilson, M.A. Structural Biology of the DJ-1 Superfamily. Adv. Exp. Med. Biol. 2017, 1037, 5-24. [CrossRef]

20. Honbou, K.; Suzuki, N.N.; Horiuchi, M.; Niki, T.; Taira, T.; Ariga, H.; Inagaki, F. The crystal structure of DJ-1, a protein related to male fertility and Parkinson's disease. J. Biol. Chem. 2003, 278, 31380-31384. [CrossRef]

21. Tao, X.; Tong, L. Crystal structure of human DJ-1, a protein associated with early onset Parkinson's disease. J. Biol. Chem. 2003, 278, 31372-31379. [CrossRef]

22. Kleifeld, O.; Doucet, A.; auf dem Keller, U.; Prudova, A.; Schilling, O.; Kainthan, R.K.; Starr, A.E.; Foster, L.J.; Kizhakkedathu, J.N.; Overall, C.M. Isotopic labeling of terminal amines in complex samples identifies protein N-termini and protease cleavage products. Nat. Biotechnol. 2010, 28, 281-288. [CrossRef]

23. Soneoka, Y.; Cannon, P.M.; Ramsdale, E.E.; Griffiths, J.C.; Romano, G.; Kingsman, S.M.; Kingsman, A.J. A transient three-plasmid expression system for the production of high titer retroviral vectors. Nucleic Acids Res. 1995, 23, 628-633. [CrossRef]

24. Encinas, M.; Iglesias, M.; Liu, Y.; Wang, H.; Muhaisen, A.; Cena, V.; Gallego, C.; Comella, J.X. Sequential treatment of SH-SY5Y cells with retinoic acid and brain-derived neurotrophic factor gives rise to fully differentiated, neurotrophic factor-dependent, human neuron-like cells. J. Neurochem. 2000, 75, 991-1003. [CrossRef] [PubMed]

25. Tholen, S.; Biniossek, M.L.; Gansz, M.; Ahrens, T.D.; Schlimpert, M.; Kizhakkedathu, J.N.; Reinheckel, T.; Schilling, O. Double deficiency of cathepsins B and L results in massive secretome alterations and suggests a degradative cathepsin-MMP axis. Cell. Mol. Life Sci. CMLS 2014, 71, 899-916. [CrossRef] [PubMed]

26. Chen, C.Y.; Melo, E.; Jakob, P.; Friedlein, A.; Elsasser, B.; Goettig, P.; Kueppers, V.; Delobel, F.; Stucki, C.; Dunkley, T.; et al. $\mathrm{N}$-Terminomics identifies HtrA1 cleavage of thrombospondin-1 with generation of a proangiogenic fragment in the polarized retinal pigment epithelial cell model of age-related macular degeneration. Matrix Biol. 2018, 70, 84-101. [CrossRef] [PubMed]

27. Kleifeld, O.; Doucet, A.; Prudova, A.; auf dem Keller, U.; Gioia, M.; Kizhakkedathu, J.N.; Overall, C.M. Identifying and quantifying proteolytic events and the natural $\mathrm{N}$ terminome by terminal amine isotopic labeling of substrates. Nat. Protoc. 2011, 6, 1578-1611. [CrossRef]

28. Shahinian, H.; Loessner, D.; Biniossek, M.L.; Kizhakkedathu, J.N.; Clements, J.A.; Magdolen, V.; Schilling, O. Secretome and degradome profiling shows that Kallikrein-related peptidases 4, 5, 6, and 7 induce TGFbeta-1 signaling in ovarian cancer cells. Mol. Oncol. 2014, 8, 68-82. [CrossRef]

29. Koczorowska, M.M.; Friedemann, C.; Geiger, K.; Follo, M.; Biniossek, M.L.; Schilling, O. Differential effect of TGFbeta on the proteome of cancer associated fibroblasts and cancer epithelial cells in a co-culture approach-A short report. Cell Oncol. 2017, 40, 639-650. [CrossRef]

30. Cox, J.; Mann, M. MaxQuant enables high peptide identification rates, individualized p.p.b.-range mass accuracies and proteomewide protein quantification. Nat. Biotechnol. 2008, 26, 1367-1372. [CrossRef] [PubMed]

31. Schilling, O.; Huesgen, P.F.; Barre, O.; Auf dem Keller, U.; Overall, C.M. Characterization of the prime and non-prime active site specificities of proteases by proteome-derived peptide libraries and tandem mass spectrometry. Nat. Protoc. 2011, 6, 111-120. [CrossRef] [PubMed]

32. Tyanova, S.; Temu, T.; Sinitcyn, P.; Carlson, A.; Hein, M.Y.; Geiger, T.; Mann, M.; Cox, J. The Perseus computational platform for comprehensive analysis of (prote)omics data. Nat. Methods 2016, 13, 731-740. [CrossRef]

33. Ritchie, M.E.; Phipson, B.; Wu, D.; Hu, Y.; Law, C.W.; Shi, W.; Smyth, G.K. limma powers differential expression analyses for RNA-sequencing and microarray studies. Nucleic Acids Res. 2015, 43, e47. [CrossRef] [PubMed]

34. Alexa, A.; Rahnenfuhrer, J.; Lengauer, T. Improved scoring of functional groups from gene expression data by decorrelating GO graph structure. Bioinformatics 2006, 22, 1600-1607. [CrossRef]

35. Wickham, H.; Averick, M.; Bryan, J.; Chang, W.; McGowan, L.; François, R.; Grolemund, G.; Hayes, A.; Henry, L.; Hester, J.; et al. Welcome to the Tidyverse. J. Open Source Softw. 2019, 4, 1686. [CrossRef]

36. Neuwirth, E. ColorBrewer Palettes [R package RColorBrewer version 1.1-2]. 2014. Available online: http:/ / colorbrewer2.org/ (accessed on 1 December 2020).

37. Li, K.; Vaudel, M.; Zhang, B.; Ren, Y.; Wen, B. PDV: An integrative proteomics data viewer. Bioinformatics 2019, 35, 1249-1251. [CrossRef] 
38. Schneider, C.A.; Rasband, W.S.; Eliceiri, K.W. NIH Image to ImageJ: 25 years of image analysis. Nat. Methods $2012,9,671-675$. [CrossRef]

39. Murillo, J.R.; Goto-Silva, L.; Sanchez, A.; Nogueira, F.C.S.; Domont, G.B.; Junqueira, M. Quantitative proteomic analysis identifies proteins and pathways related to neuronal development in differentiated SH-SY5Y neuroblastoma cells. EuPA Open Proteom. 2017, 16, 1-11. [CrossRef]

40. Biniossek, M.L.; Nagler, D.K.; Becker-Pauly, C.; Schilling, O. Proteomic identification of protease cleavage sites characterizes prime and non-prime specificity of cysteine cathepsins B, L, and S. J. Proteome Res. 2011, 10, 5363-5373. [CrossRef]

41. Dolgacheva, L.P.; Berezhnov, A.V.; Fedotova, E.I.; Zinchenko, V.P.; Abramov, A.Y. Role of DJ-1 in the mechanism of pathogenesis of Parkinson's disease. J. Bioenerg. Biomembr. 2019, 51, 175-188. [CrossRef]

42. Andreeva, A.; Bekkhozhin, Z.; Omertassova, N.; Baizhumanov, T.; Yeltay, G.; Akhmetali, M.; Toibazar, D.; Utepbergenov, D. The apparent deglycase activity of DJ-1 results from the conversion of free methylglyoxal present in fast equilibrium with hemithioacetals and hemiaminals. J. Biol. Chem. 2019, 294, 18863-18872. [CrossRef]

43. Pfaff, D.H.; Fleming, T.; Nawroth, P.; Teleman, A.A. Evidence Against a Role for the Parkinsonism-associated Protein DJ-1 in Methylglyoxal Detoxification. J. Biol. Chem. 2017, 292, 685-690. [CrossRef]

44. Cao, J.; Chen, X.; Ying, M.; He, Q.; Yang, B. DJ-1 as a Therapeutic Target Against Cancer. Adv. Exp. Med. Biol. 2017, 1037, $203-222$. [CrossRef] [PubMed]

45. Gao, H.; Yang, W.; Qi, Z.; Lu, L.; Duan, C.; Zhao, C.; Yang, H. DJ-1 protects dopaminergic neurons against rotenone-induced apoptosis by enhancing ERK-dependent mitophagy. J. Mol. Biol. 2012, 423, 232-248. [CrossRef] [PubMed]

46. Nash, Y.; Schmukler, E.; Trudler, D.; Pinkas-Kramarski, R.; Frenkel, D. DJ-1 deficiency impairs autophagy and reduces alphasynuclein phagocytosis by microglia. J. Neurochem. 2017, 143, 584-594. [CrossRef]

47. Krebiehl, G.; Ruckerbauer, S.; Burbulla, L.F.; Kieper, N.; Maurer, B.; Waak, J.; Wolburg, H.; Gizatullina, Z.; Gellerich, F.N.; Woitalla, D.; et al. Reduced basal autophagy and impaired mitochondrial dynamics due to loss of Parkinson's disease-associated protein DJ-1. PLoS ONE 2010, 5, e9367. [CrossRef]

48. Li, J.; Liu, D.; Sun, L.; Lu, Y.; Zhang, Z. Advanced glycation end products and neurodegenerative diseases: Mechanisms and perspective. J. Neurol. Sci. 2012, 317, 1-5. [CrossRef] [PubMed]

49. Abdallah, J.; Mihoub, M.; Gautier, V.; Richarme, G. The DJ-1 superfamily members YhbO and YajL from Escherichia coli repair proteins from glycation by methylglyoxal and glyoxal. Biochem. Biophys. Res. Commun. 2016, 470, 282-286. [CrossRef]

50. Advedissian, T.; Deshayes, F.; Poirier, F.; Viguier, M.; Richarme, G. The Parkinsonism-associated protein DJ-1/Park7 prevents glycation damage in human keratinocyte. Biochem. Biophys. Res. Commun. 2016, 473, 87-91. [CrossRef]

51. Choi, D.; Kim, J.; Ha, S.; Kwon, K.; Kim, E.H.; Lee, H.Y.; Ryu, K.S.; Park, C. Stereospecific mechanism of DJ-1 glyoxalases inferred from their hemithioacetal-containing crystal structures. FEBS J. 2014, 281, 5447-5462. [CrossRef]

52. Richarme, G.; Dairou, J. Parkinsonism-associated protein DJ-1 is a bona fide deglycase. Biochem. Biophys. Res. Commun. 2017, 483, 387-391. [CrossRef] [PubMed] 